\title{
Effect of Irradiation with Visible Light (Green, Red, Blue) on Inhibition of Melanin Biosynthesis
}

\author{
Kyung-Run Ko \\ Department of Beauty, Seoyeong University, Gwangju, Korea
}

Corresponding author: Kyung-Run Ko, Department of Beauty, Seoyeong University, Seogang-ro, Buk-gu, Gwangju 61268, Korea Tel.: +82 625205286

Fax: +8262520 5286

Email: keg8500@seoyeong.ac.kr

Received November 20, 2020

Revised February 2, 2021

Accepted March 2, 2021

Published March 30, 2021

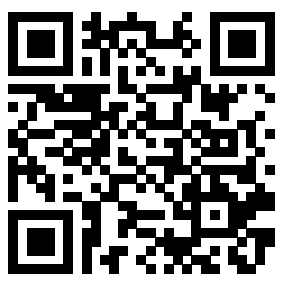

\begin{abstract}
Purpose: This study aims to investigate the inhibitory effect and regulatory mechanism of melanin biosynthesis in mouse-derived B16 melanoma cells (B16F10), using a light emitting diode (LED) light source irradiation device of three single wavelengths $(630,470,525 \mathrm{~nm}$ ) for irradiation of visible light (green, red, blue). Methods: Using three single-wavelength LED light sources, cytotoxicity, tyrosinase activity, and melanin biosynthesis were measured. Results: LED irradiation with green, red, and blue wavelengths did not show cytotoxicity or changes in melanin content at each wavelength. When the wavelength was irradiated alone, the blue and green LED wavelengths caused a decrease in tyrosinase activity, blocking the intracellular signaling mechanism that caused the increase in tyrosinase activity induced by $\alpha$-melanocyte-stimulating hormone ( $\alpha-\mathrm{MSH})$. In addition, protein kinase $\mathrm{A}$ cascade, an intracellular signaling mechanism that causes an increase in tyrosinase activity induced by $\alpha-\mathrm{MSH}$, was blocked, as it was inhibited with cyclic adenosine monophosphate (CAMP). Red series wavelength LED did not lead to any reaction. Conclusion: The irradiation of blue and green series wavelength LEDs among visible lights controls the mechanism involved in melanin formation in skin cells and results in skin whitening, which suggests that it can be effective in the whitening and cosmetic industry using LED in the future.
\end{abstract}

Keywords: LED, Meranogenesis, B16 melanoma cell, Tyrosinase, Whitening

\section{Introduction}

20세기부터 상처 등 인체 질환을 치료 관리하는 방법을 위하여 광 조사기를 사용한 예가 보고되고 있는데 그 중의 하나는 레이저를 광 원으로 사용하는 방법이다(Cheon et al., 2007). 주로 사용 될 수 있 는 레이저로서는 헬륨-네온을 기반으로 하는 $632 \mathrm{~nm}$ 파장대를 갖 는 것과 GaAlAs을 기반으로 하는 660-950 nm에 해당하는 레이저 를 사용할 수 있는데 이는 상처의 종류 및 깊이, 또한 파장의 종류에 따라 세포의 증식도를 조절하고, 통증억제, 항염증 기능을 가지며, 상처 치유를 돕는 효과 등이 있다고 보고된 바 있다(Baxter et al., 1991; Sakurai et al., 2000). 그러나 레이저는 에너지가 커서 세포 손상의 우려가 있어 저출력 레이저를 사용 할 수 있다. 이 경우 특정 세포에서 높은 증식을 보일 수 있음이 보고되었고, 세포배양, 당뇨 쥐 그리고 사람에서 $\mathrm{LED}$ 를 조사함으로 세포 증식이 증가하고 상처 치유에 효과가 있음을 보고한 바 있다(Cheon, 2008; Whelan et al., 2004).
$\mathrm{LED}$ 는 사용자와 피 사용자의 다양한 상황과 사용목적에 따라서 적절한 광 출력과 특정 파장을 선택함으로써 유해한 자외선이나 불 필요한 적외선 등이 방출되지 않는 장점으로 부작용의 위험이 적다. 그리고 사용하는 에너지가 낮음으로 조직이나 눈을 손상시키지 않는 장점이 있어서 가시광선과 근적외선 영역의 $\mathrm{LED}$ 광원을 이용한 치 료를 인간에게 사용할 수 있도록 미국 FDA에서 허가하고 있다(Kim et al., 2010). $\mathrm{LED}$ 의 또 다른 특징으로는 수명이 길고, 소비전력이 적으며 부피를 최소화 할 수 있는 장점이 있어서 환경 친화적인 장점 도 가지고 있다(Kim et al., 2010).

현재까지 밝혀진 $\mathrm{LED}$ 를 이용한 치료분야로서는 상처치유, 여드 름치유, 피부재생, 피부 각화증 치료, 알러지 비염, 항염증(Kim et al., 2013; Lim et al., 2007), 신생아 황달, 구강점막염증, 정맥 궤 양 등으로 알려져 있다. 이렇게 $\mathrm{LED}$ 의 다양한 특장점을 과학적으로 분석과 입증을 통해 임상 치료영역에서 활용되어지고 있는 반면, 아 직까지 미용영역 중 피부 미백 활성 연구 분야는 아직도 더 밝혀 내 
야 할 미진한 분야가 많은 것이 현실이다(Kim et al., 2010).

또한 최근 $\mathrm{LED}$ 를 이용한 건강관련 산업이 대두 되고 있고 살균기기, 공기정화기능, 식물 생장촉진기능, 피부활성화기능(Lee et al., 2007), 항염기능, 피부노화억제(Barolet et al., 2009), 자외선차단 및 과 색소 침착 감소(Barolet \& Boucher, 2008) 등의 많은 연구 성과가 제시되고 있고, 피부의 재생은 기술도입단계로 비침습성, 부작용 없음, 환자의 순응성, 사용의 편리성, 만족할만한 효과 등 자가 미용 치료기로서 시 장에서 각광을 받을 것으로 판단된다. 특히 피부의 재생 및 피부질환을 효과적으로 치료 관리할 수 있는 기기의 개발은 의료비용 절감, 치료 및 관리의 물리적 소요시간의 절감, 환자의 만족도 증가 등 국민생활의 질을 개선하는데 그 필요성과 중요성이 있다. 그러나 이러한 기술은 외 국을 비롯한 국내에서도 응용분야를 확장하고 있으며 활발하게 연구되 고 있으나, 국내에서는 세부 기술 개발 및 제품 개발 지원이 부족하고 향후 피부관련 치료기의 개발의 중요성이 대두되고 있다. 외국의 경우 관련 병원용 대형의 고가 의료기기들을 출시하고 있고 많은 연구가 지 속적으로 이루어지고 있다.

이와 같이 $\mathrm{LED}$ 의 경제성 및 레이저와 같은 고 에너지의 광 조사 기 구의 단점에 관한 연구를 대체하기 위한 다양한 파장에서의 $\mathrm{LED}$ 의 탐 색 및 중요성에 관한 제안은 많았지만 대부분의 연구는 동물 세포쥐를 이용한 연구에 머무르고 있어 체계적인 연구를 위해서는 다양한 LED 광원을 활용 하여 동물 세포에서의 확실한 파장을 선별하는 것은 매우 중요하다 할 것이다. 그러나 다양한 파장의 혼합체인 빛을 파장별로 분 리하고 조사함으로써 세포수준에서 멜라닌의 합성 조절 기능에 관한 연구는 미흡하였다.

본 연구는 가시광선 $(630,470,525 \mathrm{~nm}) \mathrm{LED}$ 조사장치를 활용하여 mouse 유래 B16 melanoma cell에서 멜라닌의 합성 및 조절 기전을 규 명하여 피부노화 및 피부미백 미용기기로 개발될 수 있는 가능성을 제 시하고자 한다.

\section{Methods}

\section{LED광원 및 조사}

$\mathrm{LED}$ 조사장치의 광원은 다양한 파장의 가시광성을 방출하는 고휘 도 $\mathrm{LED}$ 램프를 사용하였다. 가시광선 조사량은 조사시간과 조사거리 로 결정하였으며, 세포를 가시광선 조사용 박스에 넣은 후 $15 \mathrm{~min}$ 점 등 $/ 15 \mathrm{~min}$ 소등을 반복하여 조사하였다.

멜라닌 함량과 타이로시나아제 활성을 촉진시키기 위하여 세포 배
양액에 $\alpha-\mathrm{MSH}$ 등의 자극원을 사용할 수 있으며, 그 농도는 별도로 정 한다.

미용 LED 보드의 제작은 본 연구자의 실험 디자인 및 설계 내용에 따라서 주문제작을 실시하였고 제작 및 공급 회사는 (주)엠아이테크 이 며, 제원은 1.1 와트 $(\mathrm{W}), 12$ 볼트, 0.1 암페어 (A)의 규격을 사용하였으 며, $50 \times 50 \mathrm{~mm}$ 크기의 기판에 $3 \times 3$ 열의 배열로 $\mathrm{LED}$ 조사기판을 제작 하였다. 구체적인 $\mathrm{LED}$ 조사장치의 파장 및 조합은 Table 1 과 같다.

$\mathrm{LED}$ 조사를 위해서 $20 \times 30 \times 15 \mathrm{~cm}(\mathrm{~W} \times \mathrm{L} \times \mathrm{H})$ 크기의 빛이 투 과하지 못하는 종이 재질의 박스를 제작하고 고압멸균을 실시하였 다. 제작된 $\mathrm{LED}$ 는 박스의 상단 중앙에 동일한 크기의 구멍을 내어 $3 \mathrm{M}$ 테이프로 고정하였고 내부로 조사되는 광선이 다른 박스 내부로 들어가지 못하도록 인큐베이터 각층은 차폐를 실시하였다. 각 LED 의 조사시간을 통일시키기 위하여 전원부에는 $24 \mathrm{~h}$ 타이머를 설치하 여 $15 \mathrm{~min}$ 점등 $/ 15 \mathrm{~min}$ 소등이 반복되도록 하였다.

\section{B16 melanoma cell}

B16 melanoma cell은 American Type Culture Collection (ATCC) 로부터 구입하여 사용하였고, 배지는 $10 \%$ fetal bovine serum (FBS) 을 포함한 $\mathrm{DMEM}$ 배지를 사용하였으며, 온도 $37^{\circ} \mathrm{C}$ 와 $5 \%$ 의 $\mathrm{CO}_{2}$ 를 유지하는 incubator에서 배양하였다. 배지는 매 2 일마다 교환하였으 며, 세포의 밀도가 $90 \%$ 가 도달하기 이전에 계대배양하였다. 냉동 보 관한 세포를 해동한 후 내지 5-6 passage 까지만 사용하였으며, 사 용 후 세포는 고압멸균 후 폐기하였다.

\section{3. 시약 및 기기}

1) 시약

시약으로 dimethyl sulfoxide (DMSO; Sigma Chem. Co., USA), fetal bovine serum (FBS; Wellgene, Korea), 3-(4,5-dimethylthiazol-2-yl)-2,5-diphenyl-tetrazolium bromide (MTT; Sigma Chem), Dulbecco's Modified Eagle's Medium (DMEM; Invitrogen, USA), tyrosinase (mushroom; Sigma Chem), L-3,4-dihydroxy-L-phenylalanine (L-DOPA; Sigma Chem), $\alpha$-melanocyte stimulating hormone ( $\alpha-\mathrm{MSH}$; Sigma Chem)을 사용하였고, 이외 실험 중 사용한 buffer 및 시약들 은 시판되는 특 1 급 이상의 시약으로 직접 조제하였다.

2) 기기

실험에 사용한 기기는 Centrifuge (Vision sci. co., Korea), $\mathrm{CO}_{2}$

\section{Table 1. List of LED boards}

\begin{tabular}{ll}
\hline No & \multicolumn{1}{c}{ LED board } \\
1 & LED board red 3 lines $/ 630 \mathrm{~nm}, 1.1 \mathrm{~W}(12 \mathrm{~V} \times 0.09 \mathrm{~A}), 50 \times 50 \mathrm{~mm}$ \\
2 & LED board blue 3 lines $/ 470 \mathrm{~nm}, 1.1 \mathrm{~W}(12 \mathrm{~V} \times 0.09 \mathrm{~A}), 50 \times 50 \mathrm{~mm}$ \\
3 & LED board green 3 lines $/ 525 \mathrm{~nm}, 1.1 \mathrm{~W}(12 \mathrm{~V} \times 0.09 \mathrm{~A}), 50 \times 50 \mathrm{~mm}$ \\
\hline
\end{tabular}




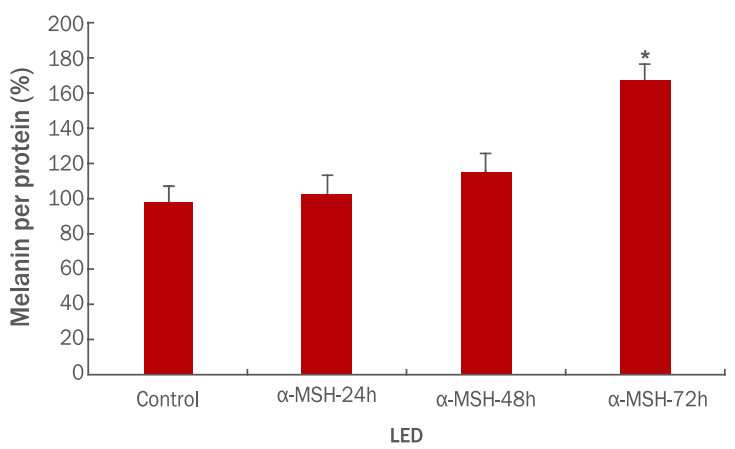

Figure 1. Changes of melanin contents in B16 melanoma cell by treatment of $\alpha-\mathrm{MSH}$.

Cells were incubated with $10 \mathrm{nM} \alpha-\mathrm{MSH}$ for indicated periods and measured melanin contents. Data are presented as the mean of three independent experiments $\pm \mathrm{SD}$; ${ }^{*} p<0.01$ versus the control group; $\alpha$-MSH, $\alpha$-melanocyte-stimulating hormone; LED, light emitting diode.

incubator (Vision Scientific Co., Korea), Microscope (Olympus, Japan), ELISA reader (Molecular Devices, USA), water bath (Vision Scientific)을 사용하였다.

\section{MTT assay}

본 실험에서 B16 melanoma cell에 대한 sample들의 처리 농도를 결정하기 위해 MTT assay를 사용하였는데, 이 정량법은 Mosmann (1983)의 방법을 변형하여 실시하였다. 이 분석법은 노란색의 수용 성 기질인 MTT를 진청색의 비수용성인 formazan 질로 변화시키는 살아있는 세포의 mitochondria dehydrogenase의 능력을 이용한 방 법이다. 생성된 formazan의 양은 살아있는 세포 수에 비례한다.

세포를 배양하여 96 well plate에 각 well당 세포를 $10^{5}$ 개 정도 되 게 배지와 함께 $180 \mu \mathrm{L}$ 를 넣고 $\mathrm{LED}$ 를 설치하여 조사할 수 있도록 제작된 박스에 plate를 넣고 배양기 $\left(37^{\circ} \mathrm{C}, 5 \% \mathrm{CO}_{2}\right)$ 에서 표시된 시간 동안 배양 후 MTT용액 $(0.5 \mathrm{mg} / \mathrm{ml}) 50 \mu \mathrm{L}$ 를 넣어 4 시간 동안 다시 배양한다. 상층액을 제거하고 formazan 침전물에 $150 \mu \mathrm{L}$ 의 DMSO 를 넣어 $15 \mathrm{~min}$ 실온에서 방치하여 formazan을 녹이고 $570 \mathrm{~nm}$ 의 파장에서 ELISA reader로 흡광도를 측정하여 세포 생존율을 계산한 다. 결과는 control에 대한 \%로 나타낸다.

Viability $(\%$ of control $)=($ A570 sampls $/$ A570 control $) \times 100$

A570: absorbance at $570 \mathrm{~nm}$

\section{B16 melanoma cell내의 tyrosinase 활성도 및 melanin생성 량 측정}

1) Tyrosinase 활성도 측정

세포를 배양하여 96 well plate에 각 well당 세포를 $10^{5}$ 개 정도씩 넣고 반응군으로 $\mathrm{LED}$ 를 설치하여 조사할 수 있도록 제작된 박스에

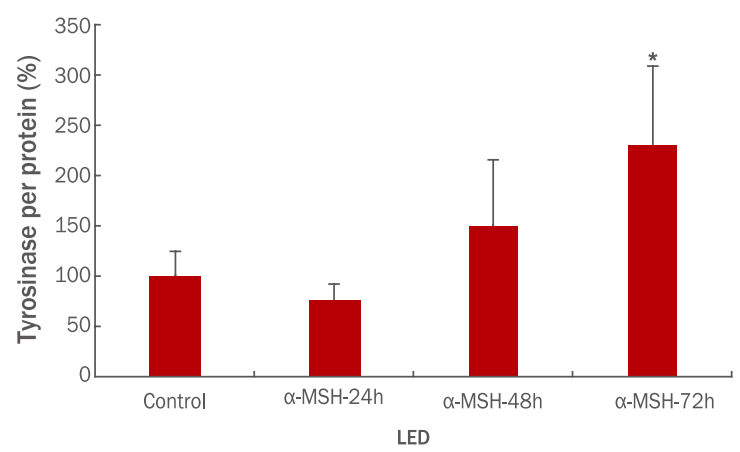

Figure 2. Changes of intracellular tyrosinase activities of B16 melanoma cell by treatment of $\alpha-M S H$.

Cells were incubated with $10 \mathrm{nM} \alpha-\mathrm{MSH}$ for indicated periods and measured tyrosinase activities. Data are presented as the mean of three independent experiments $\pm \mathrm{SD} ;{ }^{*} p<0.05$ versus the control group; $\alpha-\mathrm{MSH}, \alpha$-melanocyte-stimulating hormone; LED, light emitting diode.

plate를 넣고 배양기 $\left(37^{\circ} \mathrm{C}, 5 \% \mathrm{CO}_{2}\right)$ 에서 표시된 시간 동안 배양 후 각 well의 세포를 $10 \mathrm{mM}$ phosphate buffered saline (PBS)으로 세 척하였으며, Triton X-100 1\%를 함유한 $10 \mathrm{mM} \mathrm{PBS} 100 \mu \mathrm{L}$ 에 현 탁시켰다. 현탁된 이 액을 vortexing한 후 원심분리하여 상층액을 활 성측정 용액으로 사용하였다.

96 well plate에 이 효소액을 $40 \mu \mathrm{L}$ 넣고 기질인 L-DOPA (2 $\mathrm{mg} / \mathrm{mL}) 100 \mu \mathrm{L}$ 를 첨가하였다. $37^{\circ} \mathrm{C}$ 에서 $1 \mathrm{~h}$ 동안 반응을 진행시 킨 뒤, ELISA reader를 이용하여 $405 \mathrm{~nm}$ 에서 흡광도를 측정하였다. Tyrosinase의 활성도는 아래와 같은 식으로 계산하였다.

활성도 $(\%)=(\mathrm{A} 405$ 반응군 $/ \mathrm{A} 405$ control $) \times 100$

A405: absorbance at $405 \mathrm{~nm}$

\section{2) Melanin 생성량 측정}

세포를 배양하여 96 well plate에 각 well당 세포를 $10^{5}$ 개씩 넣고 반응군으로 $\mathrm{LED}$ 를 설치하여 조사할 수 있도록 제작된 박스에 plate 를 넣고 배양기 $\left(37^{\circ} \mathrm{C}, 5 \% \mathrm{CO}_{2}\right)$ 에서 표시된 시간 동안 배양 후 표기 된 시간동안 배양한 후 각 well의 세포를 $10 \mathrm{mM} \mathrm{PBS}$ 으로 세척한 후 $0.2 \mathrm{~N} \mathrm{NaOH}$ 용액 $400 \mu \mathrm{L}$ 를 첨가하고 $60^{\circ} \mathrm{C}$ 에서 $1 \mathrm{~h}$ 동안 용해하였 으며, ELISA reader를 이용하여 $405 \mathrm{~nm}$ 에서 흡광도를 측정하였다. 멜라닌 양은 합성 멜라닌을 사용하여 작성된 표준 직선에서 구할 수 있고, 실험군의 멜라닌 양은 대조군의 멜라닌 양에 대한 백분율로 구 한다.

\section{6. $\alpha-\mathrm{MSH}$ 에 의한 tyrosinase 활성 및 과생성 melanin에 미치는 영향}

외부자극에 따른 B16 melanoma cell내 tyrosinase의 활성 및 과 생성 멜라닌에 각 sample들이 어떤 영향을 미치는지를 알아보기 위 


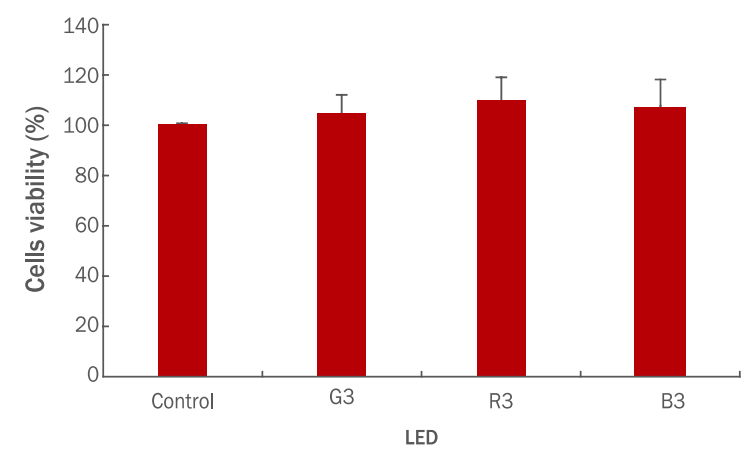

Figure 3. Endogeneous cytotoxicities of LED.

Cells were incubated with both LEDs for $72 \mathrm{~h}$ and cell viability was measured by MTT assay. Data are presented as the mean of three independent experiments $\pm S D$. ${ }^{*} p<0.05$ versus the control group; G3, green; R3, red; B3, blue; LED, light emitting diode; MTT, 3-(4,5-dimethylthiazol-2-yl)-2,5-diphenyl-tetrazolium bromide.

해 외부자극제로 $\alpha-\mathrm{MSH}$ 를 사용하였다. $\alpha-\mathrm{MSH}$ 는 멜라닌 세포의 표면에 존재하는 특이적인 수용체와 결합하고, $\alpha-\mathrm{MSH}$ 와 그 수용 체의 복합체가 세포내의 $\mathrm{cAMP}$ 를 증가시킴으로써 멜라닌 합성이 증 가되는 것으로 알려져 있다(Cha, 2018; Shim, 2019). 약물농도는 $\alpha-\mathrm{MSH} 100 \mathrm{mM}$ 로 정하였다. Tyrosinase 활성도와 과생성 멜라닌 의 생성량 측정은 Choi et al. (1995)의 방법을 그대로 이용하여, 농 도별로 조제한 각 sample, arbutin, 외부자극제 $(\alpha-\mathrm{MSH})$ 를 세포에 처리한 후 tyrosinase 활성도 및 과생성 멜라닌 양을 측정하였다.

\section{7. 통계처리}

모든 실험은 3 회 반복으로 실시하여 평균표표준편차 값으로 표 현하였다. 통계처리는 방법은 SPSS 10.0 및 Sigma Plot 10.0 software를 사용하여 student $t$-test를 실시하였으며 $p$ 값이 0.05 미만일 때 유의한 것으로 판단하였다 $(p<0.05)$.

\section{Results and Discussion}

\section{1. $\alpha-\mathrm{MSH}$ 에 의한 멜라닌 생합성량 확인}

B16 melanoma cell에 멜라닌의 생합성을 증가시키는 대표적 인 호르몬인 $\alpha$-melanine synthesis hormone ( $\alpha-\mathrm{MSH})$ 을 처리함 으로써 멜라닌 합성능이 최고에 달하는 시간지점을 설정하기 위하 여 실험을 실시한 후 그 결과를 Figure 1에 나타내었다. $10 \mathrm{nM}$ 의 $\alpha-\mathrm{MSH}$ 를 24,48 , 그리고 $72 \mathrm{~h}$ 동안 B16 세포에 처리한 후 세포 내 멜라닌 함량을 colormetry 법으로 측정한 결과 배양 시간 의존적으 로 멜라닌 함량이 증가되는 것을 확인할 수 있었다. 특히 $72 \mathrm{~h}$ 배양 세포에서는 대조군에 비하여 $70 \%$ 가까이 멜라닌의 함량이 증가되는 것을 확인함으로써 $(p<0.01)$, 향후 시험에 $72 \mathrm{~h}$ 의 배양 조건이 최적

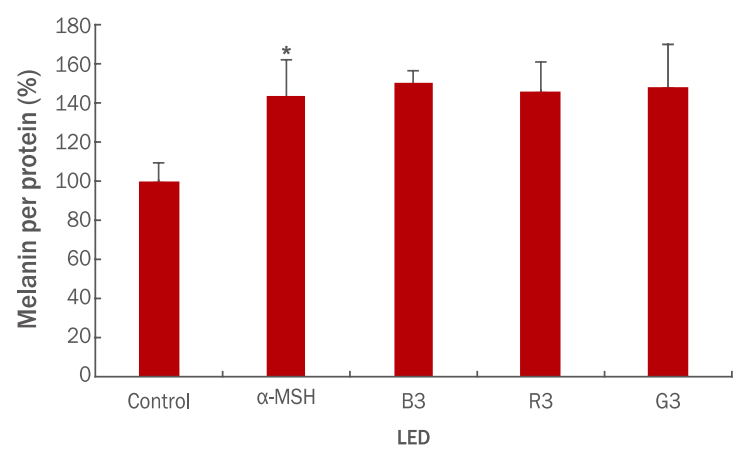

Figure 4. Changes of melanin contents by LED irradiation.

Cells were incubated in the presence or absence of $\alpha-\mathrm{MSH}$ and both LEDs for $72 \mathrm{~h}$. Cells were then solubilized and melanin contents were measured. Data are presented as the mean of three independent experiments $\pm \mathrm{SD}$; ${ }^{*} p<0.05$ versus the control group; $\alpha$-MSH, $\alpha$-melanocyte-stimulating hormone; B3, blue; R3, red; G3, green; LED, light emitting diode.

임을 제시하는 결과를 획득하였다.

\section{2. $\alpha-\mathrm{MSH}$ 에 의한 tyrosinase 활성 변화 확인}

B16 melanoma cell에 tyrosinase의 활성을 증가시키는것으로도 알려진 $\alpha-\mathrm{MSH}$ 을 처리함으로써 tyrosinase의 활성이 최고에 달하는 시간지점을 설정하기 위하여 실험을 실시한 후 그 결과를 Figure 2 에 나타내었다. $10 \mathrm{nM}$ 의 $\alpha-\mathrm{MSH}$ 를 24,48 , 그리고 $72 \mathrm{~h}$ 동안 B16 melanoma cell에 처리한 후 세포 내 tyrosinase의 활성을 DOPA 를 이용한 colormetry 법으로 측정한 결과 배양 시간 의존적으로 tyrosinase의 활성이 유의하게 증가되는 것을 확인할 수 있었다. 특 히 $72 \mathrm{~h}$ 배양 세포에서는 대조군에 비하여 $125 \%$ 이상 tyrosinase 활 성이 증가되는 것을 확인함으로써( $p<0.05)$, 향후 시험에 $72 \mathrm{~h}$ 의 배 양 조건이 최적임을 제시하는 결과를 획득하였다. 그러나 효소 활성 측정 시 소요되는 세포의 생리학적 특성으로 인해 오차 범위가 큰 것 을 확인하였으나 유의성 평가 결과 $72 \mathrm{~h}$ 배양 조건은 향후 실험에서 최적의 조건으로 활용할 수 있음을 알 수 있다.

\section{3. 가시광선(green, red, blue)조사에 의한 세포 독성 확인}

가시광선 파장 중 대표적인 색상인 녹색, 적색, 청색 계열 LED 를 조사함으로써 B16 melanoma cell에 발생할 수 있는 독성을 평 가하기 위하여 본 시험을 실시한 후 그 결과를 Figure 3에 나타내었 다. 상기에 명시된 호르몬 처리에 의한 세포 내 멜라닌의 형성능과 tyrosinase 활성을 비교한 조건과 동일한 조건인 $72 \mathrm{~h}$ 동안 $15 \mathrm{~min}$ 점등/15 min 소등을 반복하여 세포에 조사하였고 MTT assay를 통 하여 세포 생존율을 비교하였다. 그 결과, $72 \mathrm{~h}$ 동안 녹색, 적색, 청 색 계열 $\mathrm{LED}$ 를 B16 melanoma cell에 조사함으로써 세포의 유의한 증감은 관찰되지 않았고, 이는 녹색, 적색, 청색 계열 $\mathrm{LED}$ 를 조사는 


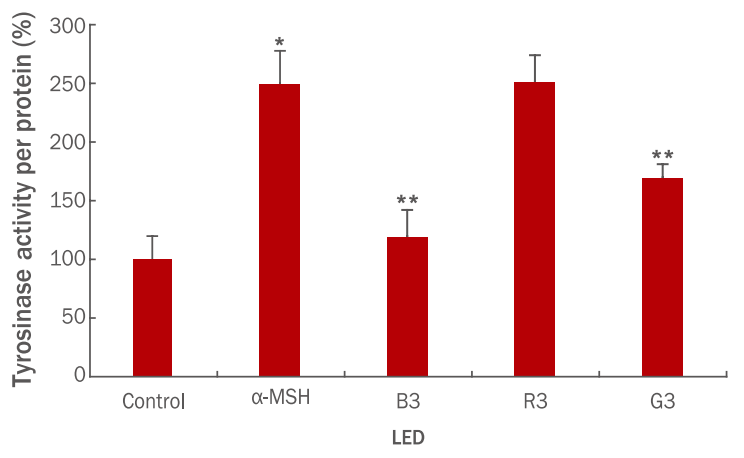

Figure 5. Changes of intracellular tyrosinase activities by LED irradiation.

Cells were incubated in the presence or absence of $\alpha-\mathrm{MSH}$ and both LEDs for $72 \mathrm{~h}$. The cells were then solubilized and tyrosinase activities were measured. Data are presented as the mean of three independent experiments $\pm \mathrm{SD}$; ${ }^{*} p<0.05$ versus the control group; B3, blue; R3, red; G3, green; $\alpha-M S H, \alpha$-melanocytestimulating hormone; LED, light emitting diode.

세포의 증식 또는 사멸에 직접적인 관여는 하지 않는 것으로 판단되 었다. 이러한 결과는 녹색, 적색, 청색 계열 $\mathrm{LED}$ 의 조사는 세포 독성 을 갖고 있지 않음을 증명하는 것이라 할 수 있다.

그러나 Cheon (2008)은 $633 \mathrm{~nm} \mathrm{LED} \mathrm{광원을} \mathrm{단독으로} \mathrm{사용할} \mathrm{경}$ 우 세포증식율을 높인다는 결과를 보고하여 이를 종합해보면 광 조 사 시 특정 파장의 선별적 사용이 효과적임을 시사한다.

\section{4. 가시광선(green, red, blue)조사에 의한 melanin 생합성도 변 화 확인}

녹색, 적색, 청색 계열 $\mathrm{LED}$ 를 조사함으로써 B16 melanoma cell 의 내부에서 $\alpha-\mathrm{MSH}$ 에 의해 유도된 멜라닌의 생합성 증가를 억제하 는지 확인하는 실험을 진행한 후 그 결과를 Figure 4 에 나타내었다. Figure 2에서 확인한 바와 같이 $\alpha-\mathrm{MSH}$ 의 처리는 B16세포의 멜라 닌 생합성을 유의하게 증가시키는 것을 확인하였다. 그러나 녹색, 적 색, 청색 계열 $\mathrm{LED}$ 를 조사를 통해 멜라닌의 함량을 조절하는지를 확 인하였을 때 각 파장의 광원 조사는 멜라닌 함량의 유의한 변화를 보 이지 않았다. 이러한 결과는 녹색, 적색, 청색 계열 $\mathrm{LED}$ 의 조사는 멜 라닌의 생합성 및 축적에 영향을 미치지 않는 것으로 판단된다. 이처 럼 가시광선 조사는 멜라닌 합성에는 영향을 미치지 않았지만 이와 반대로 레드 $(630 \mathrm{~nm})$ 와 그린 $(520 \mathrm{~nm})$ 파장이 섬유아세포에 영향을 미쳐 세포의 증가가 보고되어졌고(Kim et al., 2015), 레드(633 nm) 파장에서는 세포증식이 보고되어졌다(Cheon, 2008).

\section{5. 가시광선(green, red, blue)조사에 의한 tyrosinase 활성 변화 확인}

녹색, 적색, 청색 계열 $\mathrm{LED}$ 를 조사는 멜라닌 함량을 변화시키지

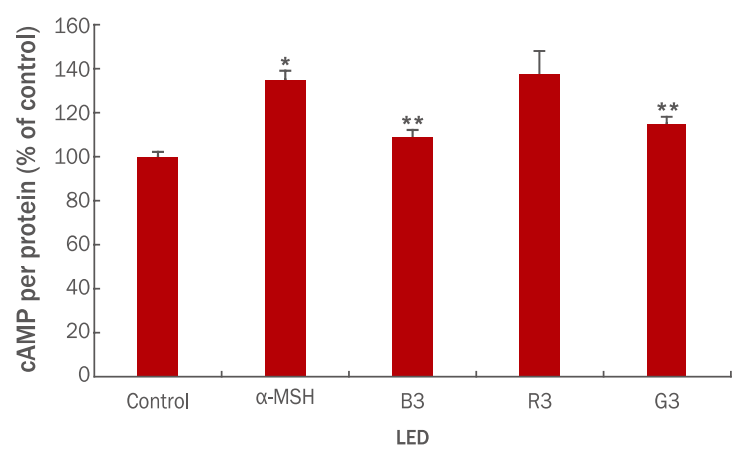

Figure 6. Changes of intracellular cAMP concentration by LED irradiation.

Cells were incubated in the presence or absence of $\alpha$-MSH and both LEDs for $72 \mathrm{~h}$. The cells were then solubilized and tyrosinase activities were measured. Data are presented as the mean of three independent experiments $\pm \mathrm{SD}$; ${ }^{*} p<0.05$ versus the control group; cAMP, cyclic adenosine monophosphate; $\alpha-\mathrm{MSH}$, $\alpha$-melanocyte-stimulating hormone; B3, blue; R3, red; G3, green; LED, light emitting diode.

않았으나 멜라닌의 생합성에 중요한 기전으로 작용하는 tyrosinase 활성의 변화를 측정한 후 그 결과를 Figure 5 에 나타내었다. $\alpha-\mathrm{MSH}$ 를 처리한 후 녹색, 적색, 청색 계열 $\mathrm{LED}$ 를 $72 \mathrm{~h}$ 동안 처리 하였고, tyrosinase 활성을 측정하였다. 동시에 96 well plate에서 단 백질 양을 측정함으로써 단백질 당량당 tyrosinase 활성으로 환산하 여 백분율로 표시한 결과 $\alpha-\mathrm{MSH}$ 처리에 의한 tyrosinase 활성은 앞의 그림과 마찬가지로 $150 \%$ 가량의 증가를 관찰할 수 있었다. 이 에 반해 녹색, 적색, 청색 계열 $\mathrm{LED}$ 를 조사한 결과, 청색 파장 $\mathrm{LED}$ 를 조사한 경우 tyrosinase 활성은 거의 음성대조군 수준으로 감소 된 것을 확인할 수 있었고( $p<0.01)$, 그 다음으로 녹색 계열의 파장 이 유의하게 tyrosinase 활성이 감소된 것을 확인할 수 있었다. 이 에 반해, 적색 계열의 가시광선 파장의 조사는 $\alpha-\mathrm{MSH}$ 에 의해 유 도된 tyrosinase 활성의 증가의 변화가 관찰되지 않았다. 이러한 결 과는 청색 계열의 파장과 녹색 계열의 파장은 $\alpha-\mathrm{MSH}$ 에 의해 유도 된 tyrosinase 활성 증가를 일으키는 세포 내 신호전달 기전을 차단 하였다는 것을 증명하고 있다. 특히 청색 계열의 가시광선 파장은 음 성대조군 수준까지 효소 활성을 감소시키는 것으로 보아 광 조사 시 간의 조절 및 구체적인 연구가 필요할 것으로 판단된다. 그러나 적색 가시광선 파장은 $\alpha-\mathrm{MSH}$ 에 의해 유도된 tyrosinase 활성을 변화 시키지 않는 것으로 보아 특정 파장만이 세포에 작용하여 효소 활성 을 변화시키는 것으로 판단할 수 있었다. 이 결과는 $660 \mathrm{~nm} \mathrm{LED}$ 가 $\mathrm{B} 16 \mathrm{~F} 10$ 세포에서 $\alpha-\mathrm{MSH}$ 에 의해 유도된 tyrosinase 활성을 억제했 다고 보고한 Oh et al. (2017)와 $830 \mathrm{~nm}$ 와 $850 \mathrm{~nm}$ LED에서 멜라 닌생성 및 tyrosinase 활성을 억제했다고 보고한 Kim et al. (2012) 의 결과와는 반대의 결과가 나왔다. 그러나 이 결과는 저장식품의 갈 
변 현상을 막기 위해 파랑, 초록 빨강색 $\mathrm{LED}$ 를 조사한 연구에서 파 란색 $\mathrm{LED}$ 에서 강도가 증가할수록 tyrosinase 활성 저해효과가 증가 하였고, 빨강 $\mathrm{LED}$ 에서는 tyrosinase 활성변화 없다는 연구 결과와 일치한다(Jung et al., 2015).

\section{6. 가시광선(green, red, blue)조사에 의한 세포내 cAMP 수준 변 화 확인}

녹색, 적색, 청색 계열 $\mathrm{LED}$ 를 조사는 멜라닌의 함량은 변화시 키지 않고 단지 tyrosinase의 활성만을 변화시키는 것을 확인한 후 Figure 6에 나타내었다. 멜라닌의 생합성은 세포내 cAMP를 증가 시킴으로 다양한 단백질을 인산화시키고 cAMP-response element binding protein (CREB)을 경유하여 microphthalmia-associated transcription factor (MITF) 활성화를 통한 tyrosinase의 gene regulation에 참여하는 것으로 알려져 있다(Smith et al., 2000). 그 렇기 때문에 세포 외부 자극에 의한 가장 상위 기전인 $\mathrm{cAMP}$ 의 활성 화를 측정하는 것이 중요하고 세포 내 $\mathrm{cAMP}$ 함량을 측정하였다. 그 결과, $\alpha-\mathrm{MSH}$ 를 $72 \mathrm{~h}$ 동안 처리한 B16 세포는 $30 \%$ 이상의 cAMP 함량이 증가되는 것을 확인할 수 있었다. 이에 반해, 청색, 녹색 계열 $\mathrm{LED}$ 를 조사하였을 때 $\alpha-\mathrm{MSH}$ 에 의해 상승된 세포내 $\mathrm{cAMP}$ 의 함량 은 유의하게 감소되었음을 확인하였다. 그러나, 적색 계열 $\mathrm{LED}$ 의 조 사는 세포내 cAMP의 수준을 변화시키지 않았으며 이는 적색 가시 광선 파장은 궁극적으로 tyrosinase 활성을 변화시키지 않으며 멜라 닌의 생합성에 영향을 미치지 않았던 이유로 설명된다. 하지만, 앞 서 제시한 멜라닌 함량변화 결과에서 본 것과 달리, 청색 또는 녹색 계열 $\mathrm{LED}$ 조사에 의해 tyrosinase 활성과 $\mathrm{cAMP}$ 함량을 변화시키는 것을 확인하였는데 이러한 결과를 볼 때 일반적인 멜라닌 합성 메커 니즘과 다른 기전을 통해 조절됨을 암시하고 있다.

\section{Conclusion}

가시광선(green, red, blue)조사를 위하여 세가지 단일 파장 $(630,470,525 \mathrm{~nm})$ 의 LED 조사장치를 활용하여 mouse 유래 B16 melanoma cell에서 멜라닌의 합성 및 조절 기전을 규명한 결과 B16 melanoma cell에서 $\alpha-\mathrm{MSH}$ 에 의한 멜라닌의 합성은 $72 \mathrm{~h}$ 배양 시 간에서 멜라닌의 함량 및 tyrosinase 활성이 최고로 나타났다.

녹색, 적색, 청색 계열 $\mathrm{LED}$ 조사는 기존의 전구와 달리 발열이 광 원자체에서는 발생하지 않고 에너지 소비 효율이 월등히 높아 열에 의한 손상은 없었음을 확인하였고, 각 파장에 의한 내재적인 세포 독 성은 관찰되지 않았다.

녹색, 적색, 청색 계열 $\mathrm{LED}$ 를 조사를 통해 멜라닌의 함량을 조 절하는지를 확인하였을 때 각 파장의 광원 조사는 멜라닌 함량에 유의한 변화를 보이지 않았으나. 청색 계열 및 녹색 계열의 파장은 tyrosinase 활성 감소를 일으켜 청색 계열 및 녹색 계열의 파장이 $\alpha-\mathrm{MSH}$ 에 의해 유도된 tyrosinase 활성 증가를 일으키는 세포 내 신호전달 기전을 차단하였다는 것을 알 수 있었다.

녹색, 적색, 청색 계열 $\mathrm{LED}$ 를 조사가 tyrosinase의 활성 조절 및 멜라닌 합성에 관여하는 protein kinase A에 관여하는 인자인 cAMP 의 형성에도 청색 및 녹색 파장이 억제 효과를 가지는 것으로 확인되 었다. 이 결과는 청색 계열의 파장과 녹색 계열의 파장은 $\alpha-\mathrm{MSH}$ 에 의해 유도된 tyrosinase 활성 증가를 일으키는 세포 내 신호전달 기 전인 protein kinase A cascade를 cAMP를 억제함을 통해 차단하였 다는 것을 증명하고 있다.

본 연구는 에너지 효율이 높고 파장 선택성이 우수한 $\mathrm{LED}$ 를 사용 하여 B16 melanoma cell에서 멜라닌의 합성에 미치는 다양한 신호 전달 기전을 조절하는 것을 확인하였고, 향후 미백 및 향장 미용 산 업에서 응용 가치가 높은 기초적인 지식과 심도 깊은 응용 분야를 제 공할 수 있을 것으로 기대한다.

\section{Author's contribution}

KRK designed, performed experiments, analyzed data, and wrote the manuscript. All figures are created by the author.

\section{Author details}

Kyung-Run Ko (Professor), Department of Beauty, Seoyeong University, Seogang-ro, Buk-gu, Gwangju 61268, Korea.

\section{References}

Barolet D, Boucher A. LED photoprevention: reduced MED response following multiple LED exposures. Lasers in Surgery and Medicine, 40: 106-112, 2008.

Barolet D, Roberge CJ, Auger FA, Boucher A, Germain L. Regulation of skin collagen metabolism in vitro using a pulsed $660 \mathrm{~nm}$ LED light source: clinical correlation with a single-blinded study. The Journal of Investigative Dermatology, 129: 2751-2759, 2009.

Baxter GD, Bell AJ, Allen JM, Ravey J. Low level laser therapy: current clinical practice on Northern Ireland. Physiotherapy, 77: 171, 1991.

Cha HJ. Cnidium officinale makino extracts inhibit $\alpha-\mathrm{MSH}-$ induced melanogenesis in B16F10 mouse melanoma cells. Asian Journal of Beauty and Cosmetology, 16: 122- 
130, 2018.

Cheon MW. Effects of LEDs light of $633 \mathrm{~nm}$ wavelength in skin of organism. Journal of the Korean Institute of Electrical and Electronic Material Engineers, 21: 760765, 2008.

Cheon MW, Kim SH, So KY, Moon YL, Mun SP, Park YP, Lee HS, Kim TG. 4-chennel light medical therapy apparatus for external injury cure. Journal of the Korean Institute of Electrical and Electronic Material Engineers, 20: 731735, 2007.

Choi JS, Lee JH, Han SY. Anti-hyperlipidemic effect of phragmitis communis and its active principles. Journal of the Korean Society of Food Science and Nutrition, 24: 523-529, 1995.

Jung HY, Kim JS, Noh BS. Effect of light emitting diode irradiation on tyrosinase activity during storage. Korean Journal of Food Science and Technology, 47: 785-788, 2015.

Kim CH, Cheong KA, Lee AY. 850nm light-emittingdiode phototherapy plus low-dose tacrolimus (FK506) as combination therapy in the treatment of dermatophagoides farinae-induced atopic dermatitis-like skin lesions in NC/Nga mice. Dermatological Science,72: 142-148, 2013.

Kim JM, Kim NH, Tian YS, Lee AY. Light-emitting diodes at 830 and $850 \mathrm{~nm}$ inhibit melanin synthesis In vitro. Acta Dermato-Venereologica, 92: 675-680, 2012.

Kim JT, Bae SB, Youn DH. Medical treatment machinery based on LED light source. Electronics and Telecommunications Trends, 25: 59-71, 2010.

Kim MN, Kwak TJ, Kang NG, Lee SH, Park SG, Lee CK. The effect of photomodulation in human dermal fibroblasts. Journal of the Society of Cosmetic Scientists of Korea, 41: 325-331, 2015.

Lee SY, Park KH, Choi JW, Kwon JK, Lee DR, Shin MS, Lee JS, You CE, Park MY. A prospective, randomized, placebo- controlled, double-blinded, and split-face clinical study on LED phototherapy for skin rejuvenation: clinical, profilometric, histologic, ultrastructural, and biochemical evaluations and comparison of three different treatment settings. Journal of Photochemistry and Photobiology B: Biology, 88: 51-67, 2007.

Lim W, Lee SG, Kim I, Chung M, Kim M, Lim H, Park J, Kim $\mathrm{O}$, Choi $\mathrm{H}$. The anti-inflammatory mechanism of $635 \mathrm{~nm}$ light-emitting-diode irradiation compared with existing COX inhibitors. Lasers in Surgery and Medicine, 39: 614621, 2007.

Mosmann T. Rapid colorimetric assay for cellular growth and survival: application to proliferation and cytotoxicity assays. Journal of Immunological Methods, 65: 55-63, 1983.

Oh CT, Kwon TR, Choi EJ, Kim SR, Seok J, Mun SK, Yoo $\mathrm{KH}$, Choi YS, Choi SY, Kim BJ. Inhibitory effect of 660$\mathrm{nm}$ LED on melanin synthesis in in vitro and in vivo. Photodermatology Photoimmunology Photomedicine, 33: 49-57, 2017.

Sakurai Y, Yamaguchi M, Abiko Y. Inhibitory effect of lowlevel laser irradiation of LPS-stimulated prostaglandin E2 production and cyclooxygenase-2 in human gingival fibroblasts. European Journal of Oral Science, 108: 2934, 2000.

Shim JH. Whitening effect of Brazilin in B16F10 cells. Asian Journal of Beauty and Cosmetology, 17: 287-294, 2019.

Smith S, Kelley P, Kenyon J, Hoover D. Tietz syndrome (hypopigmentation/deafness) caused by mutation of MITF. Journal of Medical Genetics, 37: 446-448, 2000.

Whelan HT, Smits RL Jr., Buchman EV, Whelan NT, Turner SG, Margolis DA, Cevenini V, Stinson $\mathrm{H}$, Ignatius $\mathrm{R}$, Martin $\mathrm{T}$, et al. Effect of NASA light-emitting diode irradiation on wound healing. Journal of Clinical Laser Medicine \& Surgery, 19: 305-314, 2001. 


\section{국문초록}

\section{가시광선(녹색, 적색, 청색) 조사에 따른 멜라닌 생합성 억제 효과}

고경륜

서영대학교 뷰티미용과, 광주, 한국

목적: 본 연구는 가시광선(녹색, 적색, 청색)조사를 위한 세가지 단일 파장(630, $470,525 \mathrm{~nm})$ 의 LED 광원 조사장치를 활용하여 mouse 유래 B16 melanoma cell (B16F10)에서 멜라닌의 생합성 저해 효과 및 조절 기전을 규명하고자 하는데 있다. 방법: 세가 지 단일 파장의 LED 광원을 이용하여 세포독성, tyrosinase 활성도 측정, melanin 생합성도 정도를 확인하였다. 결과: 녹색, 적색, 청색 계열 파장의 LED 조사는 각 파장에서 세포독성이 나타나지 않았으며, 멜라닌 함량은 변화가 없었다. 파장을 단독 조사하였 을 때 청색 및 녹색 계열 $\mathrm{LED}$ 파장은 tyrosinase 활성 감소를 일으켜, $\alpha-\mathrm{MSH}$ 에 의해 유도된 tyrosinase 활성 증가를 일으키는 세 포 내 신호전달 기전을 차단하였다. 또한 $\alpha-\mathrm{MSH}$ 에 의해 유도된 tyrosinase 활성 증가를 일으키는 세포내 신호전달 기전인 protein kinase A cascade를 cAMP로 억제함으로써 차단하였다. 적색 계열 파장의 LED는 반응이 나타나지 않았다. 결론: 가시광선 중 청색 및 녹색 계열 파장의 $\mathrm{LED}$ 의 조사는 피부 세포에서 멜라닌의 형성에 관여하는 메커니즘을 조절하고 피부 미백의 효과를 나타낼 수 있음을 확인하였고 향후 LED를 이용한 미백 및 향장 미용 산업에서 효과적일 수 있음을 시사한다.

핵심어: 발광 다이오드, 멜라닌 합성, B16 melanoma cell, 티로시나아제, 미백

\section{참고문헌}

김진태, 배성범, 윤두협. 피부질환 치료용 LED 치료기. 전자통신동향분석, 25: 59-71, 2010.

김미나, 곽택종, 강내규, 이상화, 박선규, 이천구. 피부 섬유아세포에서 광자극의 효과. 대한화장품학회지, 41: $325-331$, 2015.

심중현. B16F10 세포에서 브라질린의 미백 효능. 아시안뷰티화장품학술지, 17: 287-294, 2019.

정효연, 김정선, 노봉수. 저장 중 발광다이오드 광 조사가 타이로시네이스 활성에 미치는 영향. 한국식품과학회지, $47:$ 785-788, 2015

차화준. B16F10 mouse melanoma 세포에서 Cnidium officinale Makino 추출물의 $\alpha-\mathrm{MSH}$ 에 의해 유도된 melanogenesis 억제효과. 아시안뷰티화장품학술지, 16: 122-130, 2018.

천민우. $630 \mathrm{~nm}$ 파장의 LED 광원이 생체 피부에 미치는 영향. 전기전자재료학회논문지, 21: 760-765, 2008.

천민우, 김성환, 소금영, 문영래, 문성표, 박용필, 이호식, 김태곤. 체외 상처 치유를 위한 4-채널 광 치료기. 전기전자재 료학회논문지, 20: 731-735, 2007.

최재수, 이지현, 양한석. 갈대의 고지혈증 개선효과와 그 활성성분. 한국영양식량학회지, 24: 523-529, 1995. 


\section{中文摘要}

\section{可见光（绿色，红色，蓝色）照射对黑色素生物合成的抑制作用}

高炅輪

瑞永大学校美容科，广州，韩国

目的: 本研究旨在为照射可见光（绿色，红色，蓝色）使用三种单一波长（630、470、525 nm）的LED光源照 射装置, 研究黑色素生物合成对小鼠衍生的B16黑色素瘤细胞（B16F10）的抑制作用和调节机制。方法: 使用三 个单波长LED光源, 测量细胞毒性, 酪氨酸酶活性和黑色素的生物合成。结果: 绿色, 红色和蓝色波长的LED照 射在每个波长下均未显示出细胞毒性或黑色素含量的变化。当单独照射波长时, 蓝色和绿色LED波长导致酪氨酸 酶活性降低, 从而阻止了引起 $\alpha-M S H$ 诱导的酪氨酸酶活性增加的细胞内信号传导机制。另外, 蛋白激酶A级联反 应（一种引起 $\alpha-M S H$ 诱导的酪氨酸酶活性增加的细胞内信号传导机制）被阻断，因为它被CAMP抑制。红色系列 波长的LED没有引起任何反应。结论: 可见光中蓝色和绿色系列波长LED的照射控制了皮肤细胞中黑色素形成的 机制，并导致皮肤美白，这表明它将来在使用LED的美白和化妆品行业中可能是有效的。

关键词: LED，黑色素生成，B16黑色素瘤细胞，酪氨酸酶，美白 
